\author{
Andrii SOVA \\ Doctor of Philosophy, Associate Professor, \\ Department of Olympic Education \\ I. Boberskyi Lviv State University of Physical Culture \\ ORCID: https://orcid.org/0000-0003-0548-4975 \\ e-mail: andrijsova@yahoo.com
}

\title{
PHYSICAL EDUCATION PROFESSOR STEPAN HAIDUCHOK: THE FORMATION OF A WORLDVIEW
}

The study presents the first attempt to highlight the formation of Stepan Haiduchok's (1890-1976) ideological orientations based on various sources: private archives of Stepan Haiduchok (Lviv), Klavdii Bilynskyi (Sydney) and Andrii Sova (Lviv); reports of the Lviv Academic Gymnasium; Stepan Haiduchok's personal file, which was preserved at Danylo Halytskyi Lviv National Medical University; periodical of the Ukrainian gymnastic society «Sokil» - «Visti z Zaporozha»; Ivan Boberskyi's works; the memoirs of persons who knew him directly or indirectly.

With the involvement of previously unavailable and little-known documents, his childhood and high school years were reconstructed. The author has demonstrated that Professor of the Lviv Academic Gymnasium Ivan Boberskyi (1873-1947), through the gymnastics classes (physical education), the activities of the Ukrainian Sports Club and the Sokil Gymnastic Society influenced the formation and choice of Stepan Haiduchok's future profession - a physical education teacher.

During the high school years were formed the basis, which let him express himself as an athlete, professor of Ukrainian physical education, public and cultural person, journalist, editor, student, and follower of the «Father of Ukrainian Physical Education». The research methodology based on general scientific principles of historical objectivity, systematicity, reliability, complexity, and scientific nature. By applying the biographical method, it was more likely to reveal the objectives of the study.

Keywords: Stepan Haiduchok, Lviv Academic Gymnasium, Ivan Boberskyi, worldview formation, body education, physical education, sport.

Formation of a worldview, as well as the life way of Stepan Haiduchok (March 13, 1890, Pidtemne village - March 16, 1976, Lviv) - professor of Ukrainian physical education, public and cultural-enlightenment figure, journalist, editor, photographer, a soldier of the Ukrainian Halychyna's Army, athlete, one of the first Ukrainian expert in physical education and sports, a student and follower of the «Father of Ukrainian Physical Education» Ivan Boberskyi, a connoisseur of Ukrainian antiquity, still remains a little-known issue of historiography. 
In Ukrainian historiography, there are small essays about the life and work of Stepan Haiduchok by Oksana Vatseba, Bohdan Yakymovych and Roman Mozola ${ }^{1}$, Oleksandra Sluzhynska ${ }^{2}$, Oleksandr Pauk ${ }^{3}$, Andrii Sova ${ }^{4}$, and others. Researchers' special attention deserves the photo album, which published part of a unique collection of photographs, postcards, and documents collected by Stepan Haiduchok during his life, which are now kept by Lesia Krypiakevych. The photo album has an introduction about the collection, a short biographical essay about his life, the destiny of his daughter Bogdana's family, the era of Professor Stepan Haiduchok ${ }^{5}$. Brief biographical information concerning Stepan Haiduchok is presented in reference books. The first such works appeared after World War II among Ukrainian diaspora, in particular in the «Encyclopedia of Ukrainian Studies» ${ }^{6}$ and the anniversary book of the Lviv Academic Gymnasium ${ }^{7}$. Most are presented in modern Ukrainian encyclopedias, reference books, dictionaries, and guides ${ }^{8}$. In 2017, in the book «Ivan Boberskyi - the Founder of the Ukrainian Physical Education and Sports Tradition», the author of the article noted: «in the near future the works of Professor Ivan Boberskyi and his students Stepan Haiduchok, Taras and Petro Frankiv, Oleksandr Tysovskyi, Oksana

\footnotetext{
1 Вацеба О., Мозола М. Сівач зерна добра на рідній ниві. «Сокіл-Батько»: спортивно-руханкове товариство у Львові. Альманах 1894-1994 / упоряд. А. Благітка. Львів: Основа, 1996. С. 80-83; Вацеба О., Якимович Б. Сівач зерна добра на рідній ниві. Гайдучок Степан: Воєнні спомини / уклад. і авт. передм. О. Вацеба, Б. Якимович. Львів: Видавничий центр ЛНУ імені Івана Франка, 2002. С. 5-11. (Серія «Мемуари і документи», ч. 2).

2 Служинська О. Степан Гайдучок - лікар Четвертої Золочівської бригади УГА. Украйнський інформаційний бюлетень здоров'я. Львів, 2005. Квітень-червень. С. 79-80.

3 Паук О. Згадаймо призабуті імена - Степан Гайдучок. URL: http://galsports.com/news/zhadaymopryzabuti-imena-stepan-hayduchok/57221.aspx (дата звернення: 8.09.2014).

4 Сова А., Тимчак Я. На пошану професора Степана Гайдучка - одного з перших фахівців тіловиховання і спорту в Україні. Нам спорт. Неперіодичний спортовий журнал украӥнського спортово-виховного товариства «Чорноморська Січ» (Випені) 2016. Чис. 52. С. 26-27; Сова А. Степан Гайдучок - творець та літописець історії українського тіловиховання. Шлях Перемоги (Київ; Лондон; Мюнхен; Нью-Йорк; Торонто). 2018. 14 березня. Чис. 11 (3324). С. 7.

5 Галичина - український здвиг за матеріалами архіву Степана Гайдучка: [Альбом] / авт. ідеї Л. Крип'якевич; упоряд.: Ю. Николишин, І. Мельник; літ. ред. І. Лемко. Львів: Апріорі, 2014. $268 \mathrm{c}$.

${ }^{6}$ Гайдучок Степан. Енциклопедія украйнознавства. Словникова частина / гол. ред. В. Кубійович. Париж; Нью-Йорк: Молоде Життя, 1955. Т. 1. С. 338.

7 Сениця П. Професори Української Академічній Гімназії у Львові. Ювілейна книга Украӥнської Академічної гімназії у Львові. На 100-річчя першого украйнського іспиту зрілости 1878-1978 / упоряд., літ. та техн. ред. Б. Романенчука. Філядельфія; Мюнхен, 1978. С. 139-140.

8 Личаківський некрополь. Путівник. Львів, 2006. С. 439; Литвин М. Р. Гайдучок Степан. Енциклопедія Сучасної Украӥни. Київ, 2006. Т. 5: Вод-Гн. С. 309; Мовчан С. Гайдучок Степан. Енциклопедія Львова / за ред. А. Козицького та І. Підкови. Львів: «Літопис», 2007. Т. 1. С. 437-438; Зіменковський Б. С., Гжеготський М. Р., Луцик О. Д. Професори Львівського національного медичного університету імені Данила Галицького: 1784-2009. Львів: Наутіліус, 2009. С. 59-60; Сова А. Гайдучок Степан Степанович. Західно-Українська Народна Республіка 1918-1923. Енциклопедія. Івано-Франківськ, 2018. Т. 1: А-Ж. С. 309-310.
} 
Sukhoverska, Daria Navrotska, and others, will be the theoretical basis for the formation of the national base of physical culture in renewed Ukraine 9 .

Despite the studies mentioned above, the life and creative work of Stepan Haiduchok have not yet become the subject of a separate in-depth scientific study. Considering this, the author prepared an article, which, for the first time, reconstructs the professor's childhood and high school years based on various sources.

The sources for the study were: the personal file of Stepan Haiduchok, which has been preserved in the Danylo Halytskyi Lviv National Medical University; publications of the Ukrainian society «Sokil» - «Visty z Zaporozha»; works of Ivan Boberskyi; reports of the Lviv Academic Gymnasium; private archives of Stepan Haiduchok (Lviv), Klavdii Bilynskyi (Sydney), Andrii Sova (Lviv); memories of people who knew Stepan Haiduchok directly or indirectly.

Stepan Haiduchok was born in the village Pidtemne (now the village in the Pustomyty district of the Lviv region) in a peasant family of Stepan (? - 1893) and Mariia (1856-1916). In his autobiography, dated February 27, 1950, he wrote about his childhood and youthful years: «I was born in 1890-13 / III. in the village Pidtemne, Shchyrets district, Lviv region in a family of middle-class peasants. My father died [leaving] me a child in about 1893, my mother in 1916. I had an older brother and an older sister. Both were peasants. My brother died in 1943, and my sister, apparently in 1946, I do not know the exact year. My father's and mother's family lived in the village Semenivka [now the village in the Pustomyty district of the Lviv region. - A.S.], also peasants. Ukrainian by nationality» ${ }^{10}$. From the quote, we can conclude that Stepan Haiduchok lost his father at the age of three. He and two other children, an older brother and sister, were raised by their mother. As for information about the middle peasants: in 1950, Stepan Haiduchok worked at the Lviv State Medical Institute and deliberately had to submit such data not to expose himself to unnecessary trouble. In fact, according to residents of Pidtemne, Stepan Haiduchok's family was among the richest in the village. Today the lands they owned in the late 20th - early 20th century called «Haidukivka», «Haidukova Dolyna», etc ${ }^{11}$.

On March 13, 1890, Stepan Haiduchok received the sacrament of baptism and confirmation in the church of Pidtemne (unfortunately, the church has not survived to this day). «The Birth and Baptism Certificate of Stefan Haiduchok» stated that his parents were Stefan Haiduchok and Mariia (maiden name Dyky), who lived in Pidtemne in the house № 57; godparents: Vasyl Dyky and Yevdokiia - wife of Semen Senkiv, midwife - Mariia Makovska; baptized and confirmed the local pastor Yevstakhii Merunovych ${ }^{12}$. Firstly, he studied at a primary school in his native village Pidtemne, and from 1901 to 1910 at the Lviv Academic Gymnasium. In 1902/1903, he had a break from school. From high school reports, we found out that Stepan Haiduchok studied well. In 1904, as a student of the 2nd

\footnotetext{
9 Сова А., Тимчак Я. Іван Боберський - основоположник української тіловиховної і спортової традиції / за наук. ред. Є. Приступи. Львів: ЛДУФК; Апріорі, 2017. С. 206.

${ }^{10}$ Особова справа Степана Гайдучка. Архів Львівського начіонального медичного університету імені Данила Галиџького. Спр. 8413. Арк. 18.

${ }^{11}$ Спогади Кулик Ольги / записав А. Сова 20.03.2014 р. у с. Підтемному Пустомитівського р-ну Львівської обл.: відеозапис. Приватний архів Андрія Сови (м. Львів).

${ }^{12}$ Сьвідоцтво уродин і хрещеня Стефана Гайдучка. Приватний архів Клавдія Білинського (м. Сідней).
} 
grade, he finished the year with honors (out of thirty-seven, six were honor students) ${ }^{13}$. The following school year, Stepan Haiduchok attended gymnastics class (ruhanka) taught by Ivan Boberskyi on Mondays. He showed the best results in gymnastics each school year. Thus, in the first half of 1904/1905 A.Y. he was «very good», the second half of 1904/1905 A.Y. - «very good», the first half of 1905/1906 A.Y. - «good», the second half of 1905/1906 A.Y. - «honor student», the first half of 1906/1907 A.Y. - «honor student», the first half of 1907/1908 A.Y. - «honor student with admiration for the subject», the second half of 1907/1908 A.Y. - «honor student with admiration for the subject», for 1908/1909 A.Y. «very good with special admiration», for 1909/1910 A.Y. - «very good» ${ }^{14}$. The acquaintance with the physical education and Professor Ivan Boberskyi had such an impact on his future life that he became interested in this subject, began to specialize in this field, and later became a gymnastics teacher and taught it until his retirement.

Ivan Boberskyi wrote about gymnastics class: «156 students from the following classes attended gymnastics: IIIabv, IVab, V, VIab, VIIab, and VIIIab. Each of the 6 groups practiced 1 hour a week. Exercises took place in the gym of the «Sokil» society. The teacher was their mentor according to the ministry's plan from 1897. Each group was divided into three detachments exercising simultaneously under the orders of leaders chosen from among the students. The first three-quarters of an hour lasted exercises on three devices, the last part of the hour was assigned to ordinary and free exercises or games. In autumn and spring on sunny days, there were games and entertainment. Students left the gymnasium at halfpast four, and after a half-hour walk, they reached a field behind the «Imperial Woods». Games lasted from 5 to 7. After seven o'clock, the students returned home. Games took place four times a week, in four classes. Class Iabvg on Tuesday, IIabv, IIIabv on Monday, Vab, V on Friday, VIab, VIIab, VIIIab on Saturday. The first half-hour usually lasted only running games without equipment, such as: «Chornyi lytsar», «Chornomorets-Bilomorets», «Hapko», «Khody za mnoiu», «Zhhut», «Yastrub», «Tretiak», «Kit i mysh», «Khreshchyk». These were followed by ball games: «Vezha», «Plit», which prepared players for the «Miach kopanyi bez pidnymania», and ball games: «Dobuvana», «Shpurianka». In addition to the gymnastics teacher, other members of the teaching staff also taught games» ${ }^{15}$. In 1905, year

\footnotetext{
${ }^{13}$ Клясифікация учеників за другий піврік року шк. 1903/1904. Звіт дирекииї и․ к. академічноӥ тімназиї у Львові за шкільний рік 1903/1904. Львів: Накладом наукового фонду, 1904. С. 80.

${ }^{14}$ Сьвідоцтво шкільне Стефана Гайдучка за перший піврік шкільного року 1904/1905, Сьвідоцтво шкільне Стефана Гайдучка за другий піврік шкільного року 1904/1905, Сьвідоцтво шкільне Стефана Гайдучка за перший піврік шкільного року 1905/1906, Сьвідоцтво шкільне Стефана Гайдучка за другий піврік шкільного року 1905/1906, Сьвідоцтво шкільне Стефана Гайдучка за перший піврік шкільного року 1906/1907, Сьвідоцтво шкільне Стефана Гайдучка за перший піврік шкільного року 1907/1908, Сьвідоцтво шкільне Стефана Гайдучка за другий піврік шкільного року 1907/1908, Сьвідоцтво шкільне Стефана Гайдучка за шкільний рік 1908/1909, Сьвідоцтво шкільне Стефана Гайдучка за шкільний рік 1909/1910. Приватний архів Клавдія Білинського (м. Сідней).

15 [Боберський I.]. Гімнастика. Звіт дирекииї й. к. академічної тімназиї у Львові за шкільний рік 1904/1905. Львів: Накладом наукового фонду, 1905. С. 38.
} 
29 students graduated III-b class, which Stepan Haiduchok studied in ${ }^{16}$, IV-b in 1906 - 53 students ${ }^{17}$, V-b in $1907-52$ students $^{18}$, VIII-b in $1910-41$ students $^{19}$.

In 1909/1910 A.Y. Stepan Haiduchok was taught by the following teachers and professors: Vitovt Vysotskyi - Polish language teacher; professor, a lecturer at Lviv University, member of NTSH Illia Kokorudz - Latin and Greek languages; professor, assistant of the gymnasium director Edvard Kharkevych Yulian Levytskyi - history and geography; professor, adviser, and clerk of the metropolitan consistory with canon honors Rev. Leonid Luzhnytskyi - religion; Professor, Doctor of Philosophy Mykhailo Pachovskyi - Ruthenian (Ukrainian) language; Professor Yosyf Yaniv - mathematics and physics; Professor Liudvik Salio - German language. The «Master of the Class» was Illia Kokorudz. The greatest influence on him had Professor Ivan Boberskyi. The students learned a lot from the Germanlanguage library, headed by the professor ${ }^{20}$. On June 10, 1910, Stepan Haiduchok passed the maturity exam. The document stated: «Pt. 60. Imperial [Royal] Academic Gymnasium in Lviv. Certificate of maturity. Haiduchok Stefan, born on March 13, 1890, in Pidtemne in Halychyna, Greek Catholics, graduated high school education in 1902-1910 from the Imperial [Royal] Academic Gymnasium in Lviv. And he passed the maturity exam based on the ministerial order from February 29, 1908 [year], Part 10.051 (Dn. M. Part 18) for the first time. Based on this exam, he was unanimously recognized as mature for studies at the University. In Lviv on June 10, 1910 [year] $\gg^{21}$.

The influence of Professor Ivan Boberskyi at the Academic Gymnasium on the formation and choice of Stepan Haiduchok's future profession - a teacher of physical education, revealed itself in the fact that between September 1909 and May 1910 he completed state physical education courses in Prague ${ }^{22}$. At the same time, he trained guided by Ivan Boberskyi in the «Ukrainian Sports Club»» and the teachers' club of the «Sokil-Batko» society ${ }^{24}$ in Lviv. After graduating from the Lviv Academic Gymnasium on December 28-29, 1910, Stepan Haiduchok passed the state exam at the Lviv University, becoming a physical education

${ }^{16}$ Клясифікация учеників за другий піврік року шк. 1904/1905. Звіт дирекциї й. к. академічної тімназиї у Львові за шкільний рік 1904/1905. Львів: Накладом наукового фонду, 1905. С. 73.

17 Клясифікация учеників за другий піврік року шк. 1905/1906. Звіm дирекииї й. к. академічної тімназиї у Львові за шкільний рік 1905/1906. Львів: Накладом наукового фонду, 1906. С. 82.

${ }^{18}$ Клясифікация учеників за другий піврік року шкільного 1906/1907. Звіт дирекциї и. к. академічної тімназиї у Львові за шкільний рік 1906/1907. Львів: Накладом наукового фонду, 1907. С. 73.

${ }^{19}$ Клясифікация учеників за рік шкільний 1909/1910. Звіт дирекциї и. к. академічної тімназиї у Львові за шкільний рік 1909/1910. Львів: Накладом наукового фонду, 1910. С. 76.

20 Збір учительский з кінцем шк. року 1909/10. Звіт дирекциї и. к. академічної тімназиї у Львові за шкільний рік 1909/1910. Львів: Накладом наукового фонду, 1910. С. 3-5.

${ }^{21}$ Сьвідоцтво зрілости Стефана Гайдучка. Приватний архів Клавдія Білинського (м. Сідней).

${ }^{22}$ Особова справа Степана Гайдучка. Архів Львівського національного медичного університету імені Данила Галицького. Спр. 8413. Арк. 2.

${ }^{23}$ Сова А. Іван Боберський - засновник та ідейний натхненник Українського спортового кружка в Академічній гімназії у Львові. Галичина. Науковий $і$ культурно-просвітній краєзнавчий часопис (Івано-Франківськ). 2017. Чис. 29-30. С. 166-175.

${ }^{24}$ Сова А. Іван Боберський - провідний діяч українського сокільського руху. Украйна: культурна спадщина, національна свідомість, державність / гол. редкол. М. Литвин, упоряд. і наук. ред. М. Романюк]. Львів, 2017. С. 3-22. 
(ruhanka) teacher. After that, he got the opportunity to work as a physical education teacher at schools and gymnasiums with Polish and Ukrainian languages of instruction ${ }^{25}$. "The Certificate of Stepan Haiduchok on Passing the Exam in Physical Education» stated: «Pt./443. Certificate of teacher's exam in physical training. Haiduchok Stepan - born in Pidtemne in Halychyna on March 13, 1890, after graduating from Lviv Academic Gymnasium, based on a certificate of maturity from June 10, 1910 pt. 60, got access to the examination based on the order of the Imperial [Royal] Ministry of Education from September 10, 1870, / Diary № II / To show the ability to do the profession of physical education teacher in gymnasiums and teachers' seminaries, passed this exam before the signed Imperial [Royal] Examination Commission on December 28 and 29, 1910 with the following evaluation: Written exam / with an invigilator present/: excellent. Practical exam in calisthenics: excellent. Oral anatomy exam: satisfactory. Oral exam in physiology and hygiene of calisthenics: excellent. Oral exam in the theory of calisthenics: excellent. Based on the exam results, the signed Imperial [Royal] Examination Commission recognized Stepan Haiduchok as a remarkably capable teacher of physical education in gymnasiums and teachers' seminaries, both for men and women, with Polish and Ukrainian languages of instruction. In Lviv, on December 29, 1910, Director of the Imperial Royal Examination Commission; Prof. Dr. Henryk Kadyi by h[is own] h[and] Members of the I[mperial] R[oyal] Examination Commission: Associate Professor Dr. Evhen Piasetski, by h[is own] h[and] R. Kviatkovski by h[is own] h[and]» ${ }^{26}$.

Thus, Stepan Haiduchok's worldview was formed during high school years. Eventually, this basis let him express himself as an athlete, professor of Ukrainian physical education, public and cultural person, journalist, editor, student, and follower of the «Father of Ukrainian Physical Education». It was Ivan Boberskyi, a professor at the Lviv Academic Gymnasium, who influenced Stepan Haiduchok's choice of physical education teacher profession, through gymnastics classes, the activities of the Ukrainian Sports Club and the Sokil Gymnastics Society.

\section{REFERENCES}

1. [Boberskyi, I.]. (1905). Gimnastyka. In Zvit dyrektsyi ts. k. akademichnoi gimnazyi u Lvovi za shkilnyi rik 1904/1905. Lviv: Nakladom naukovoho fondu [in Ukrainian].

2. Boberskyi, I., Huzar, O., Kushpirenko, B., Pshepiurskyi, N., Vynnykiv, S., \& Sushko, Z. (1911, Mart 30). Zvit «Sokola-Batka» u Lvovi za rik 1910. Visty z Zaporozha. Chasopys rukhankovykh i pozharnykh tovarystv, 54-55, 8 [in Ukrainian].

3. Kliasyfikatsyia uchenykiv za druhyi pivrik roku shk. 1903/1904. (1904). In Zvit dyrektsyi ts. k. akademichnoi gimnazyi u Lvovi za shkilnyi rik 1903/1904 (p. 80). Lviv: Nakladom naukovoho fondu [in Ukrainian].

4. Kliasyfikatsyia uchenykiv za druhyi pivrik roku shk. 1904/1905. (1905). In Zvit dyrektsyi ts. k. akademichnoi gimnazyi u Lvovi za shkilnyi rik 1904/1905 (p. 73). Lviv: Nakladom naukovoho fondu [in Ukrainian].

\footnotetext{
25 Звіт «Сокола-Батька» у Львові за рік 1910. Вісти з Запорожа. Часопись руханкових і пожарних товариств / Боберський І., Гузар О., Кушпіренко Б., Пшепюрський Н. та ін Львів, 1911. 30 марта. Чис. 54-55. С. 8.

${ }^{26}$ Особова справа Степана Гайдучка. Архів Львівського національного медичного університету імені Данила Галищького. Спр. 8413. Арк. 20.
} 
5. Kliasyfikatsyia uchenykiv za druhyi pivrik roku shk. 1905/1906. (1906). In Zvit dyrektsyi ts. k. akademichnoi gimnazyi u Lvovi za shkilnyi rik 1905/1906 (p. 82). Lviv: Nakladom naukovoho fondu [in Ukrainian].

6. Kliasyfikatsyia uchenykiv za druhyi pivrik roku shkilnoho 1906/1907. (1907). In Zvit dyrektsyi ts. k. akademichnoi gimnazyi u Lvovi za shkilnyi rik 1906/1907 (p. 73). Lviv: Nakladom naukovoho fondu [in Ukrainian].

7. Kliasyfikatsyia uchenykiv za rik shkilnyi 1909/1910. (1910). In Zvit dyrektsyi ts. $k$. akademichnoi gimnazyi u Lvovi za shkilnyi rik 1909/1910 (p. 76). Lviv: Nakladom naukovoho fondu [in Ukrainian].

8. Krypiakevych, L. (2014). Halychyna - ukrainskyi zdvyh za materialamy arkhivu Stepana Haiduchka: [Albom] (Yu. Nykolyshyn, Comp.). Lviv: Apriori [in Ukrainian].

9. Kubiiovych, V. (Ed.). (1955). Haiduchok Stepan. In Entsyklopediia ukrainoznavstva. Slovnykova chastyna (Vol. 1, p. 338). Paris; New York: Molode Zhyttia

10. Lychakivskyi nekropol. Putivnyk. (2006). Lviv [in Ukrainian].

11. Lytvyn, M. R. (2006). Haiduchok Stepan. In Entsyklopediia Suchasnoi Ukrainy (Vol. 5, p. 309). Kyiv [in Ukrainian].

12. Movchan, S. (2007). Haiduchok Stepan. In A. Kozytskyi, I. Pidkova (Eds.), Entsyklopediia Lvova (Vol. 1, pp. 437-438). Lviv: «Litopys» [in Ukrainian].

13. Pauk, O. Zghadaimo pryzabuti imena - Stepan Haiduchok. Retrieved from http:// galsports.com/news/zhadaymo-pryzabuti-imena-stepan-hayduchok/57221.aspx [in Ukrainian].

14. Senytsia, P. (1978). Profesory Ukrainskoi Akademichnii Himnazii u Lvovi. In B. Romanenchuk (Comp.), Yuvileina knyha Ukrainskoi Akademichnoi himnazii u Lvovi. Na 100-richchia pershoho ukrainskoho ispytu zrilosty 1878-1978 (pp. 139-140). Philadelphia; Munich [in Ukrainian].

15. Sluzhynska, O. (2005, Kviten-cherven). Stepan Haiduchok - likar Chetvertoi Zolochivskoi bryhady UHA. Ukrainskyi informatsiinyi biuleten zdorovia, 79-80 [in Ukrainian].

16. Sova, A. (2017). Ivan Boberskyi - providnyi diiach ukrainskoho sokilskoho rukhu. Ukraina: kulturna spadshchyna, natsionalna svidomist, derzhavnist, 30, 3-22 [in Ukrainian].

17. Sova, A. (2017). Ivan Boberskyi - zasnovnyk ta ideinyi natkhnennyk Ukrainskoho sportovoho kruzhka v Akademichnii himnazii u Lvovi. Halychyna. Naukovyi i kulturnoprosvitnii kraieznavchyi chasopys, 29-30, 166-175 [in Ukrainian].

18. Sova, A. (2018). Haiduchok Stepan Stepanovych. In Zakhidno-Ukrainska Narodna Respublika 1918-1923. Entsyklopediia (Vol. 1, pp. 309-310). Ivano-Frankivsk [in Ukrainian].

19. Sova, A. (2018, Berezen 14). Stepan Haiduchok - tvorets ta litopysets istorii ukrainskoho tilovykhovannia. Shliakh Peremohy, 11 (3324), 7 [in Ukrainian].

20. Sova, A., \& Tymchak, Ya. (2016, Sichen). Na poshanu profesora Stepana Haiduchkaodnoho z pershykh fakhivtsiv tilovykhovannia i sportu v Ukraini. Nash sport. Neperiodychnyi sportovyi zhurnal ukrainskoho sportovo-vykhovnoho tovarystva «Chornomorska Sich», 52, 26-27 [in Ukrainian].

21. Sova, A., \& Tymchak, Ya. (2017). Ivan Boberskyi-osnovopolozhnyk ukrainskoi tilovykhovnoi i sportovoi tradytsii (Ye. Prystupa, Ed.). Lviv: LDUFK; Apriori [in Ukrainian]. 
22. Vatseba, O., \& Mozola, M. (1996). Sivach zerna dobra na ridnii nyvi. In A. Blahitka (Comp.), "Sokil-Batko»: sportyvno-rukhankove tovarystvo u Lvovi. Almanakh 18941994 (pp. 80-83). Lviv: Osnova [in Ukrainian].

23. Vatseba, O., \& Yakymovych, B. (2002). Sivach zerna dobra na ridnii nyvi. In (O. Vatseba, B. Yakymovych Comps.), Haiduchok Stepan: Voienni spomyny (pp. 5-11). Lviv: Vydavnychyi tsentr LNU imeni Ivana Franka [in Ukrainian].

24. Zbir uchytelskyi z kintsem shk. roku 1909/10. (1910). In Zvit dyrektsyi ts. k. akademichnoi gimnazyi u Lvovi za shkilnyi rik 1909/1910 (pp. 3-5). Lviv: Nakladom naukovoho fondu [in Ukrainian].

25. Zimenkovskyi, B. S., Gzhegotskyi, M. R., \& Lutsyk, O. D. (2009). Profesory Lvivskoho natsionalnoho medychnoho universytetu imeni Danyla Halytskoho: 1784-2009. Lviv: Nautilius [in Ukrainian].

\section{Андрій СОВА}

кандидат історичних наук, дочент, доияент кафедри олімпійської освіти Львівського державного університету фізичної культури імені Івана Боберського ORCID: https://orcid.org/0000-0003-0548-4975 e-mail: andrijsova@yahoo.com

\section{ПРОФЕСОР ТІЛОВИХОВАННЯ СТЕПАН ГАЙДУЧОК: ФОРМУВАННЯ СВІТОГЛЯДУ}

Вперше на основі різнопланових джерел: приватних архівів Степана Гайдучка (м. Львів), Клавдія Білинського (м. Сідней) та Андрія Сови (м. Львів); звітів Академічної гімназії у Львові; особової справи Степана Гайдучка, яка збереглася у Львівському національному медичному університеті імені Данила Галицького; видань українського гімнастичного товариства «Сокіл» - «Вісти з Запорожа»; праць Івана Боберського; спогадів осіб, які безпосередньо чи опосередковано знали Степана Гайдучка (1890-1976) висвітлено формування його світоглядних орієнтирів. Із залученням раніше недоступних та малознаних документів реконструйовано його дитячі та гімназійні роки. Доведено, що саме професор Академічної гімназії Іван Боберський (1873-1947) через уроки гімнастики (фізичне виховання), діяльність «Українського спортового кружка» та гімнастичного товариства «Сокіл» вплинув на формування та вибір майбутньої професії Степана Гайдучка - учителя фізичного виховання. Саме в гімназійні роки були закладені основи, які дали можливість Степанові Гайдучку проявити себе в майбутньому як спортовця, професора українського тіловиховання, громадського та культурно-просвітнього діяча, журналіста, редактора, учня і послідовника «Батька українського тіловиховання» Івана Боберського. Методологія дослідження грунтується на загальнонаукових принципах історичної об' єктивності, системності, достовірності, комплексності та науковості. Завдяки застосуванню біографічного методу вдалося 3 більшою вірогідністю розкрити поставлені завдання дослідження.

Ключові слова: Степан Гайдучок, Академічна гімназія у Львові, Іван Боберський, формування світогляду, тіловиховання, фізичне виховання, спорт. 


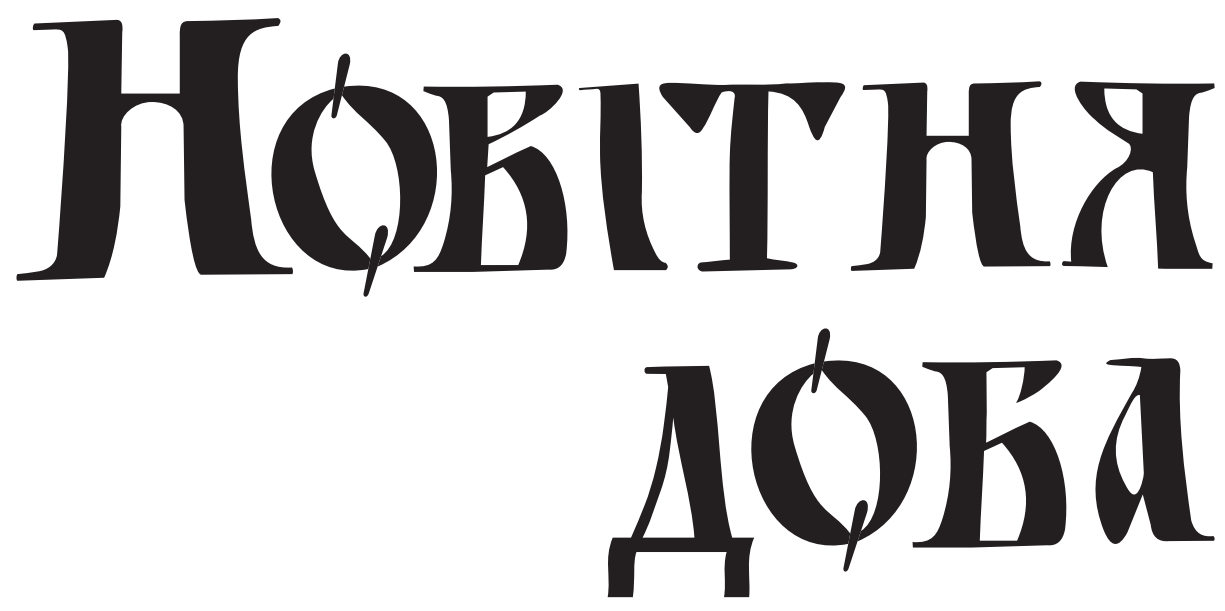

\section{випуск 7}

львІв 2019 
Новітня доба / гол. ред. Михайло Романюк; НАН України, Інститут українознавства ім. І. Крип'якевича. Львів, 2019. Вип. 7. 272 с.

У збірнику представлено дослідження з новітньої української та світової історії за період від Першої світової війни і до сьогодення. Наголошено на закономірностях й особливостях розвитку суспільно-політичних і націєтворчих процесів в Україні у контексті історії європейських народів, зокрема становища українського суспільства в умовах тоталітарних режимів. Розкрито особливості українського визвольного руху, воєнної історії, формування державних інституцій, роль культури у становленні громадянського суспільства, вивчення джерел та історичної біографістики.

Contemporary era / [resp. ed. Mykhailo Romaniuk; I. Krypiakevych Institute of Ukrainian Studies NAS of Ukraine. Lviv, 2019. Issue 7. 272 p.

The collection presents studies on modern Ukrainian and world history from the First World War to the present. Emphasis is placed on the regularities and features of the development of socio-political and nation-building processes in Ukraine in the context of the European nations' history, in particular the position of Ukrainian society under totalitarian regimes. The features of the Ukrainian liberation movement, military history, formation of state institutions, the role of culture in the development of civil society, the study of sources and historical biography are revealed.

Рекомендувала до друку вчена рада

Інституту українознавства ім. І. Крип'якевича НАН України

(протокол № 11 від 17.12.2019р.)

\section{ГОЛОВНИЙ РЕДАКТОР}

Романюк Михайло Васильович, к.і.н. (Україна)

\section{РЕДАКЦІЙНА КОЛЕГІЯ:}

Голембійовська-Тобіаш Анета (Golębiowska-Tobiasz Aneta), dr (Польща)

Дзсньковський Томаш (Dzieńkowski Tomasz), dr (Польща)

Красівський Орест Якубович, д.і.н., проф. (Україна)

Муравський Олег Іванович, к.і.н., с.н.с. (Україна)

Пасіцька Оксана Ігорівна, к.і.н. (Україна)

Патер Іван Григорович, д.і.н., проф. (Україна)

Руда Оксана Василівна, к.і.н. (Україна)

Сова Андрій Олегович, к.і.н., доц. (Україна)

Соляр Ігор Ярославович, д.і.н., с.н.с. (Україна)

Стасюк Олександра Йосипівна, к.і.н., с.н.с. (Україна)

Трофимович Лілія Володимирівна, к.і.н., доц. (Україна)

Цецик Ярослав Петрович, к.і.н., доц. (Україна) 


\section{MICT}

\section{АКТУАЛЬНІ ПРОБЛЕМИ НОВІТНЬОЇ ІСТОРІЇ}

PASITSKA Oksana. Ukrainian individual entrepreneurship in Halychyna

in the first third of the $20^{\text {th }}$ century: state and features of development ........ 3

ФІНОГЕНОВ Олег. «Українське питання» в діяльності

Західноукраїнського товариства Ліги Націй $\ldots \ldots \ldots \ldots \ldots \ldots \ldots \ldots \ldots \ldots \ldots \ldots \ldots$

ПІДШИБЯКІН Сергій. Операція чи «котел»: Дебальцівські події початку

2015 року у візіях української громадської думки . . . . . . . . . . . 23

ПОПКО Сергій. Військові навчання та миротворчі операції

Збройних сил України (2014-2016) . . . . . . . . . . . . . . . . . 38

ПОЛТАВЕЦЬ Юрій. Культурне життя, організація дозвілля та побуту

в Національній академії сухопутних військ

імені гетьмана Петра Сагайдачного . . . . . . . . . . . . . . . . . 48

\section{ПРОБЛЕМИ ДОСЛІДЖЕННЯ УКРАЇНСЬКОГО ВИЗВОЛЬНОГО РУХУ ХХ СТОЛІТТЯ}

СТЕФАНІВ Василь. Релігійне питання в ідеології європейських націоналістичних рухів та український інтегральний націоналізм

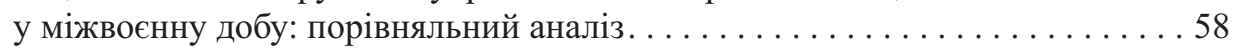

ФУТАЛА Василь. Чи була зрада в ОУН? (Історіографічні оцінки причин і передумов розколу націоналістичної організації у 1940 році) . . . . . . . . 75

БАЛЕЦЬКА Людмила. Протистояння УПА з радянськими партизанами та поляками на Камінь-Каширщині $(1943-1944)$. . . . . . . . . . . . . . . . 89

ДРОГОБИЦЬКИЙ Ігор. Еволюція концепції розгортання збройної боротьби з окупаційними режимами в середовищі ОУН(б) (1942-1944) . . . . . . . . 100

ІСАЮК Олеся. Мережа спротиву членів ОУН(б), ув'язнених у концтаборі Аушвіц: приклад трансформації тактики виживання в тактику спротиву на основі досвіду підпільного протистояння . . . . . . . 108

НАДУРАК Наталія. Ідейне протистояння українських зарубіжних і радянських дослідників в оцінці діяльності ОУН ............... 124

ПАГІРЯ Олександр. ОУН та УПА в контексті визвольних рухів: спроба компаративного аналізу. . . . . . . . . . . . . . . . . . . . 150 


\section{ПОСТАТI}

ПАТЕР Іван. Ольгерд Бочковський: ставлення чехів

і Томаша Гарріга Масарика до українського питання . . . . . . . . . . . 178

ПОСІВНИЧ Микола. Отець Степан Онишкевич: творець і будівничий ЗУНР . . . 217

SOVA Andrii. Physical education professor Stepan Haiduchok: the formation of a worldview ......................... 226

ЗАЙЦЕВ Юрій. Михайло Сорока - моральний символ борців за волю України $1940-1980-х$ років . . . . . . . . . . . . . . . . 234

\section{ОсОБЛИвий погляд}

ГАВРИЛІВ Ігор. До питання актуальності державотворчої програми

Організації Українських Націоналістів . . . . . . . . . . . . . . . . . . . . . . . . . 244

\section{ОГЛЯДИ ТА РЕЦЕНЗІї}

ARTYMYSHYN Yulia. [Рец. на:] Roman Kabachyi «Exiled to the Steppes.

The Deportation of Ukrainians from Poland

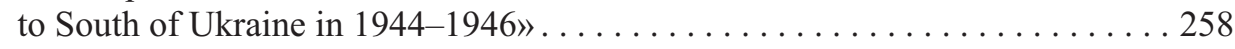

РОМАНЮК Михайло. [Рец.]: Історія УПА на Тернопільщині [на]: Волянюк С. Історія воєнної округи УПА «Лисоня» . . . . . . . . . . . 262 